\title{
SIMULATION OF POLLUTANT GAS DISPERSION ON CASE STUDY OF LONTAR 3 COAL FIRED POWER PLANT IN ADDITION INTO 1 x 660 MW CAPACITY IN KEMIRI, TANGERANG DISTRICT, BANTEN PROVINCE
}

\author{
Eko Sugiharto ${ }^{1, *}$, Taufik Abdillah Natsir ${ }^{1}$, and Abdul Rozaq ${ }^{2}$ \\ ${ }^{1}$ Department of Chemistry, Faculty of Mathematics and Natural Sciences, Universitas Gadjah Mada, \\ Sekip Utara Yogyakarta 55281, Indonesia \\ ${ }^{2}$ Center for Environmental Studies, Universitas Gadjah Mada, \\ Jl. Lingkungan Budaya, Sekip Utara, Yogyakarta 55281, Indonesia
}

Received April 10, 2014; Accepted August 7, 2014

\begin{abstract}
Air quality simulation has been performed for additional capacity of Banten $1 \times 600$ MW Coal Fired Power Plant toward air quality degradation in its surrounding environment. The simulation was based on pollutant gas dispersion calculated using Gaussian Plume equation. The research has involved climate secondary data on Cengkareng climatology Station for last 10 years. Besides, the primary data has also been taken in 7 point sampling locations to determine initial ambient air quality of existing 1 x $600 \mathrm{MW}$ Coal Fired Power Plant. The data of existing 1 x $600 \mathrm{MW}$ coal fired power plant has been taken from Adipala Steam Power Plant while the gas pollutant dispersion simulation has been done well using Gaussian Plume equation. The result showed that gas emission for $\mathrm{NO}_{2}$, and TSP parameter in all scenarios and $\mathrm{SO}_{2}$ gas parameter in several scenarios were exceeding the Threshold Limit Value. Thus, a technology is needed to minimize produced emission gas. The increase of gas pollutant in all sampling locations was not significantly increasing and those gas pollutants were not generally exceeding the threshold limit value permitted by the government regulation.
\end{abstract}

Keywords: dispersion; Gaussian Plume; Coal Fired Power Plant

\section{ABSTRAK}

Telah dilakukan penelitian simulasi kualitas udara untuk Penambahan Kapasitas PLTU Banten 1 x 600 MW terhadap penurunan kualitas udara di lingkungan sekitar. Simulasi didasarkan pada dispersi gas polutan yang dihitung dengan menggunakan persamaan Gaussian Plume. Penelitian dilakukan dengan mengambil data sekunder iklim di Stasiun Klimatologi Cengkareng selama 10 tahun. Selain itu pengambilan data primer juga dilakukan di 7 lokasi untuk menentukan kualitas udara awal sebelum penambahan kapasitas 1 x 600 MW berlaku. Data PLTU 1 x 600 MW diperoleh dari PLTU Adipala, dan simulasi dispersi gas polutan dilakukan dengan menggunakan persamaan Gaussian Plume. Hasil penelitian menunjukkan bahwa emisi gas buang untuk parameter $\mathrm{NO}_{2}$, dan TSP untuk berbagai skenario dan sebagian skenario untuk gas $\mathrm{SO}_{2}$ melebihi baku mutu emisi yang telah ditetapkan, sehingga diperlukan teknologi untuk mengurangi emisi gas yang dihasilkan. Peningkatan gas polutan di seluruh lokasi pengambilan sampel tidak mengalami peningkatan secara signifikan dan konsentrasi gas polutan masih dibawah baku mutu udara ambient yang ditetapkan oleh pemerintah

Kata Kunci: dispersi; Gaussian Plume; PLTU

\section{INTRODUCTION}

Economic growth and development process in Indonesia has increased significantly so that there is no doubt that increased consumption of energy is the primary requirement to be fulfilled to enhance national development. The World Bank noted Indonesia requires fossil energy as basic needs that increases $86 \%$ year by year from the total electricity needs by 2011 [1]. Electricity needs from renewable sources is only $14 \%$ i.e. Water Power Plant, Geothermal Power Plant, Solar Power Plant, and Wind Power Plant [2].

One of the fulfillments for electricity demand in Indonesia is produced by Coal Fired Power Plant with $48.6 \%$ of the total power generation in Indonesia and $42.4 \%$ of the total power plant using coal as its fuel [2]. Increasing pollution levels due to rapid industrialization and urbanization are now causes of major concern in industrializing countries [3]. Coal combustion for power generation and residential heating is believed to make

* Corresponding author. Tel/Fax : +62-811283602

Email address : ekosugiharto@ugm.ac.id

Eko Sugiharto et al. 
the most important contribution to atmospheric emissions [4]. The usage of power plant to meet energy necessity has also an impact for the environment such as exhaust emissions that can pollute the ambient air. The pollutant in the ambient air can contribute for atmospheric deposition. Atmospheric deposition is an important pathway for the input of nitrogen species to the watershed and water bodies [5]. Power generation emits various types of waste such as liquid waste, gas, and polluting emissions such as noise, heat emissions [6]. The major pollutants are gases and particulate matters, gases such as oxides of sulphur, nitrogen and carbon, ammonia and hydrocarbon [7]. United States Environmental Protection Agency (US EPA) states that power plants contribute air pollution because it produces pollutant gases such $\mathrm{SO}_{2}, \mathrm{NO}_{2}, \mathrm{CO}$, and particle material [8]. By burning fuels in the thermal power stations, important quantities of polluting substances such as $\mathrm{CO}, \mathrm{CO}_{2}, \mathrm{SO}_{2}, \mathrm{NO}_{2}$, ash dust are emitted into the atmosphere that have a powerful impact on the environment factors [9]. The evaluation of the maximum concentration of air pollutants such as $\mathrm{SO}_{2}, \mathrm{NO}_{\mathrm{x}}$, and suspended particulate matter is usually considered of primary importance for environmental impact assessment [10]. Analyses of the environmental effects arising from power plants using a variety of models suggest that air quality effects depend on a wide variety of local atmospheric parameters as well as on the combustion technology [11].

There are some methods to predict pollution in air environment such mathematical air pollution modeling. Mathematical air pollution modeling represents an essential tool to control and predict atmospheric pollution [12]. Gaussian plume can be used to determine pollutant dispersion in the environment [13-16]). Moreover, the Gaussian plume model is a standard approach for studying the transport of airborne contaminants due to turbulent diffusion and advection by the wind [17]. Gaussian equation can be expressed as follows:

$C(x, y, z)=\frac{Q}{2 \pi u \sigma_{y} \sigma_{z}} \exp \left(-\frac{y^{2}}{2 \sigma_{y}^{2}}\right) \times\left(\exp \left(-\frac{(z+H)^{2}}{2 \sigma_{z}^{2}}\right)+\exp \left(-\frac{(z-H)^{2}}{2 \sigma_{z}^{2}}\right)\right)$

where,

$C(x, y, z)$ : Gas concentration in $x, y, z$ coordinate $\left(g / \mathrm{m}^{3}\right)$,

$Q \quad$ : Gas emission rates from $(\mathrm{g} / \mathrm{s})$,

$\mathrm{U} \quad$ : Wind speed average $(\mathrm{m} / \mathrm{s})$,

$\sigma_{y} \quad:$ Plume standard deviation in line with y axis $(\mathrm{m})$,

$\sigma_{\mathrm{z}} \quad$ : Plume standard deviation in line with y axis $(\mathrm{m})$,

$\mathrm{H} \quad$ : Effective stack height $(\mathrm{m})$

While pollutant dispersion for particle material can be predicted from the following equation:

$C(x, y, z)=\frac{Q}{2 \pi u \sigma_{y} \sigma_{z}} \exp \left(-\frac{y^{2}}{2 \sigma_{y}^{2}}\right) \times\left(\exp \left(-\frac{\left(z+H-\frac{v_{t} x}{u}\right)^{2}}{2 \sigma_{z}^{2}}\right)+\exp \left(-\frac{\left(z-H-\frac{v_{t} x}{u}\right)^{2}}{2 \sigma_{z}^{2}}\right)\right)$ $v_{t}=g \times d^{2} \frac{\rho}{18 \mu}$

where,

$v_{t}$ : Settling velocity

$g$ : Gravity force

d : Particle diameter

$\rho$ : Particle density

$\mu$ : Air viscosity

Pollutant concentrations on ambient air are important to be determined in connection with hazardous level to the people.

PT PLN (Persero) as a supplier of electric energy, has planned to added capacity for Coal Fired Power Plant in the Lontar region in order to meet energy necessity in Jakarta and its surrounding area by building new power plant with 1 x $660 \mathrm{MW}$ capacity. The selected location is planned in Lontar village, Kemiri, Tangerang District, Banten Province. Besides, there is an existing power plant right now with of $3 x$ $315 \mathrm{MW}$ capacities. The burning of coal as energy source for power plant will emit pollutant gases which will degrade the quality of ambient air thus it is necessary to study the impact occurred of air quality deterioration. This study will examine gas emissions and pollutant dispersion with a radius of $10 \mathrm{~km}$ from the various scenarios.

\section{EXPERIMENTAL SECTION}

\section{Materials}

Material used for the research were divided into 4 types of material for every samples i.e. $\mathrm{SO}_{2}, \mathrm{NO}_{2}, \mathrm{CO}$ and TSP parameters. List of materials were based on Standar Nasional Indonesia (SNI) or Indonesian National Standard as divided as $\mathrm{SO}_{2}$ material (SNI 197119.7-2005) including Tetra Chloro Mercurate (TCM) $0.04 \mathrm{M}, \mathrm{Na}_{2} \mathrm{~S}_{2} \mathrm{O}_{5}, \mathrm{I}_{2} 0.1 \mathrm{~N}$, starch Indicator, $\mathrm{HCl}$, $\mathrm{Na}_{2} \mathrm{~S}_{2} \mathrm{O}_{3} \quad 0.1 \mathrm{~N}, \quad \mathrm{NH}_{2} \mathrm{SO}_{3} \mathrm{H} \quad 0.6 \% \quad \mathrm{~b} / \mathrm{v}, \quad \mathrm{H}_{3} \mathrm{PO}_{4}$, and $\mathrm{C}_{19} \mathrm{H}_{17} \mathrm{~N}_{3} . \mathrm{HCl} 0.2 \%$ (18). For $\mathrm{NO}_{2}$ material (SNI 197119.2-2005) such as $\mathrm{H}_{2} \mathrm{NC}_{6} \mathrm{H}_{4} \mathrm{SO}_{3} \mathrm{H}, \mathrm{CH}_{3} \mathrm{COOH}$, Aquadest, $\mathrm{C}_{12} \mathrm{H}_{16} \mathrm{Cl}_{2} \mathrm{~N}_{2}, \mathrm{C}_{3} \mathrm{H}_{6} \mathrm{O}$, and $\mathrm{NO}_{2}$ [19], while for CO material (SNI 19-4845-1998) including activated carbon, selected gel, $\mathrm{H}_{2} \mathrm{SO}_{4}$ and $\mathrm{L}_{2} \mathrm{O}_{5}$ crystal [20]. In addition, for TSP material (SNI 19-7119.3-2005), glass fiber filter, silica fiber filter and cellulose filter were used [21].

\section{Instrumentation}

Instrumentation used for the research were divided into 4 types of material for every samples i.e. $\mathrm{SO}_{2}, \quad \mathrm{NO}_{2}, \mathrm{CO}$ and TSP parameters. List of instrumentations were based on Standar Nasional Indonesia (SNI) or Indonesian National Standard as 


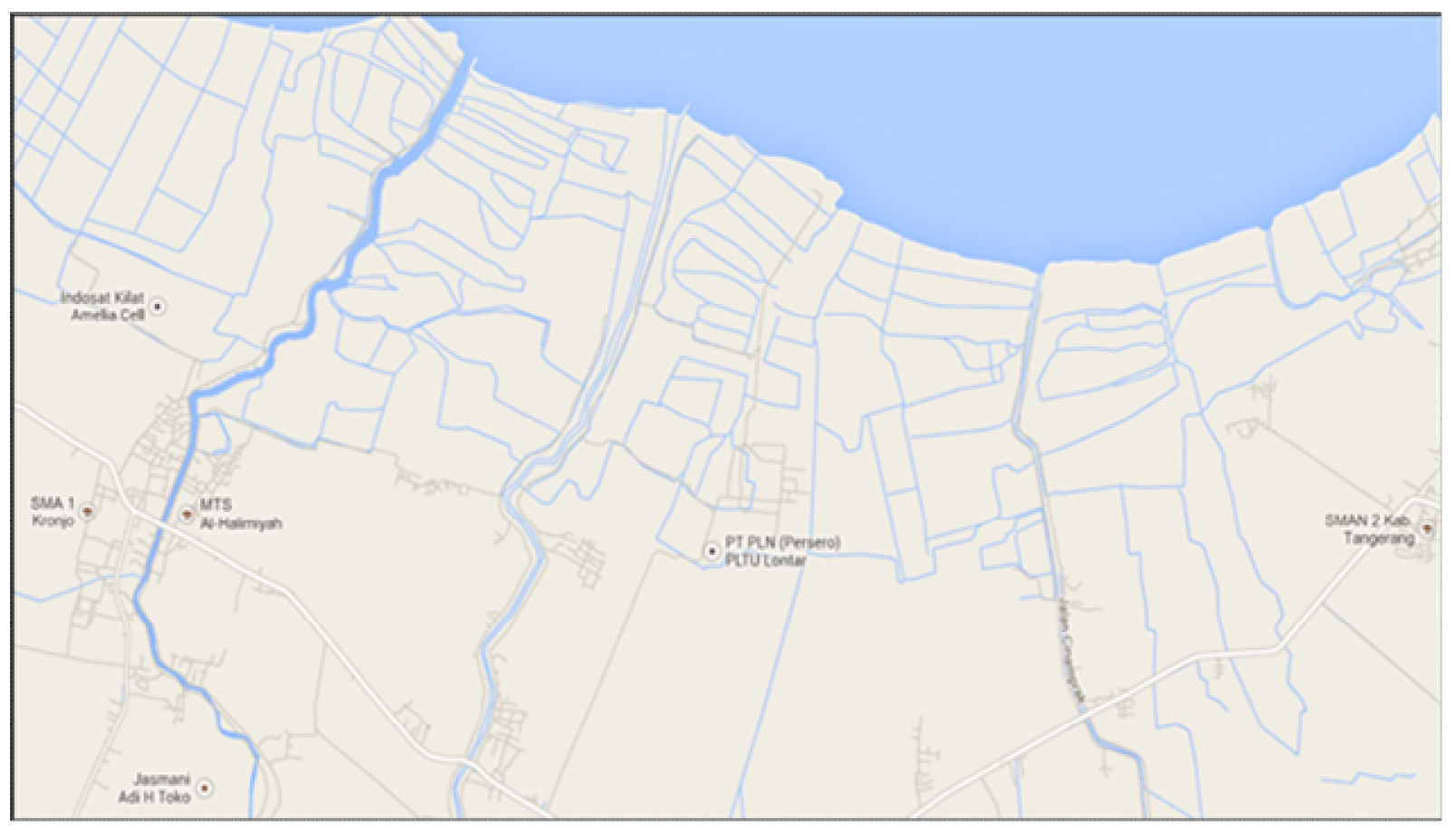

Fig 1. Location of Lontar Coal Fired Power Plant

Table 1. Modeling scenarios

\begin{tabular}{ccccccc}
\hline No & Name & $\begin{array}{c}\text { Concentration } \\
\text { of coal }\end{array}$ & Excess air & $\begin{array}{c}\text { Chimney } \\
\text { total }\end{array}$ & $\begin{array}{c}\text { Chimney } \\
\text { diameter }(\mathrm{m})\end{array}$ & Pollutant \\
\hline 1 & Case-1 & & - & Single (1) & 6.7 & \\
2 & Case-2 & \multirow{2}{*}{390} & - & Double (2) & 5.2 & $\mathrm{SO}_{2}, \mathrm{NO}_{2}$, \\
3 & Case-3 & & $10 \%$ & Single (1) & 6.7 & $\mathrm{CO}, \mathrm{TSP}$ \\
4 & Case-4 & & $10 \%$ & Double (2) & 5.2 & \\
\hline
\end{tabular}

divided as $\mathrm{SO}_{2}$ instrumentations (SNI 19-7119.7-2005) [18] as well as $\mathrm{NO}_{2}$ instrumentations (SNI 19-7119.22005) with UV-Vis Spectrophotometer [19], while CO instrumentations (SNI 19-4845-1998) with Non Dispersive Infra Red (NDIR) [20] and for TSP instrumentations (SNI 19-7119.3-2005) High Volume Air Sampler (HVAS) was used [21].

\section{Procedure}

Research location of Lontar power plant carried out in Lontar village, Kemiri, Tangerang District, Banten Province (Fig. 1). It was about 20 miles from Cengkareng, Tangerang. The meteorological data was taken in Cengkareng Climatology Station. Meteorological data used were wind speed, wind direction, and temperature for last 10 years.

The scenario used in this modeling was to calculate the load consumption of coal used and its accompanying air mass thus it would be obtained flow rate in the chimney for each dimension of chimney that will be used. Air mass necessity was calculated as stoichiometric (theoretical) of the composition of element content in coal with oxygen necessity in the air. The air mass for each weight of coal used was determined by the composition of the coal used, where was calculated by equation [9]:

$U_{o g}=11.5 \mathrm{C}+34.5\left(\mathrm{H}-\frac{\mathrm{O}}{8}\right)+4.325 \quad \mathrm{U}_{\mathrm{ov}}=\frac{\mathrm{U}_{\mathrm{L}}}{1.29}$

where,

$\mathrm{U}_{\mathrm{og}} \quad=$ Theoretical air necessity $\left(\mathrm{kg}_{\text {air }} / \mathrm{kg}_{\text {coal }}\right)$

$\cup_{\text {ov }} \quad=$ Theoretical air necessity $\left(\mathrm{m}_{\text {air }}^{3} / \mathrm{kg}_{\text {coal }}\right)$

$\mathrm{C}, \mathrm{H}, \mathrm{O}$ and $\mathrm{S}=\mathrm{C}, \mathrm{H}, \mathrm{O}$ and $\mathrm{S}$ fraction on each $\mathrm{kg}$ of coal (\%)

The study was done by modeling some parameters to get a massive amount of emissions and pollutants dispersion of gaseous pollutants in the ambient air in the study area. Its summary can be seen in Table 1.

Air quality samplings were conducted for $24 \mathrm{~h}$ for $\mathrm{SO}_{2}, \mathrm{NO}_{2}, \mathrm{CO}$ and TSP parameters in 7 residential locations closest to Lontar Power Plant. The analysis of gases was performed using pararosaniline method for $\mathrm{SO}_{2}$, Gries Saltzman for $\mathrm{NO}_{2}$, NDIR method for $\mathrm{CO}$, and the gravimetric method using high volume air samplers 
Table 2. Emission factor for gas emission of coal fired power plant using bituminous and subbituminous coal

\begin{tabular}{ll}
\hline \multicolumn{1}{c}{ Parameter } & $\begin{array}{c}\text { Coal emission factor } \\
\text { (lb/ton) }\end{array}$ \\
\hline $\mathrm{SO}_{2}$ & $38 \mathrm{~S}$ \\
$\mathrm{NO}_{2}$ & 22 \\
$\mathrm{NOx}$ (with low NOx Burner) & 11 \\
$\mathrm{CO}$ & 0.5 \\
$\mathrm{PM}(\mathrm{TSP})$ & $10 \mathrm{~A}$ \\
$\mathrm{PM}-10$ & $2.3 \mathrm{~A}$ \\
$\mathrm{PM}-2,5$ (uncontrol) & $0.6 \mathrm{~A}$ \\
$\mathrm{PM}-2,5$ (ESP) & $0.024 \mathrm{~A}$
\end{tabular}

Source: US EPA, 1993 (with $A=$ Coal Ash Content and $S=$ Coal Sulphur Content)

Table 3. Typical coal specification

\begin{tabular}{clcr}
\hline No & \multicolumn{1}{c}{ Parameter } & Unit & Amount \\
\hline 1 & Coal necessity & ton & 349.4 \\
2 & Calorific value (HHV) & k.Cal/kg & 4200 \\
3 & Coal contents & & \\
& a. Ash content & $\%$ & 5 \\
& b. Sulphur content (daf) & $\%$ & 0.4 \\
& c. Carbon & $\%$ & 68.57 \\
& d. Hydrogen & $\%$ & 5.16 \\
& e. Nitrogen & $\%$ & 1.18 \\
& f. Oxygen & $\%$ & 24.76 \\
\hline
\end{tabular}

Table 4. Pollutant flow rate

\begin{tabular}{|c|c|c|c|}
\hline Parameter & \multicolumn{2}{|c|}{ Value } & Unit \\
\hline Excess air & 0 & $10 \%$ & \\
\hline Chimney diameter & & & \\
\hline Uog & 8.61 & 9.47 & $\mathrm{~kg}$ air $/ \mathrm{kg}$ coal \\
\hline Air necessity /kg coal & 8.61 & 9.47 & $\mathrm{~kg} / \mathrm{s}$ \\
\hline Total air necessity & 933.31 & 1026.65 & $\mathrm{~kg} / \mathrm{s}$ \\
\hline $\begin{array}{l}\text { Air necessity + coal } \\
\text { Flow rate }\end{array}$ & 1041.65 & 1134.98 & $\mathrm{~kg} / \mathrm{m}^{3}$ \\
\hline $\begin{array}{l}\text { Single stack (stack } \\
\text { diameter } 6.7 \mathrm{~m} \text { ) }\end{array}$ & 34.34 & 37.41 & $\mathrm{~m} / \mathrm{s}$ \\
\hline $\begin{array}{l}\text { Double stack (stack } \\
\text { diameter 5.2) }\end{array}$ & 28.50 & 31.05 & $\mathrm{~m} / \mathrm{s}$ \\
\hline
\end{tabular}

Table 5. Emission result based on coal consumption load

\begin{tabular}{cccccc}
\hline \multirow{2}{*}{ No } & \multirow{2}{*}{ Name } & \multicolumn{4}{c}{ Pollutant concentration $\left(\mathrm{mg} / \mathrm{Nm}^{3}\right)^{1}$} \\
\cline { 3 - 6 } & & $\mathrm{SO}_{2}$ & $\mathrm{NO}_{2}$ & $\mathrm{CO}$ & $\mathrm{TSP}$ \\
\hline 1 & Case-1 & 808.01 & 1169.49 & 26.57 & 2657.93 \\
2 & Case-2 & 808.01 & 1169.49 & 26.57 & 2657.93 \\
3 & Case-3 & 741.56 & 1073.32 & 24.39 & 2439.37 \\
4 & Case-4 & 741.56 & 1073.32 & 24.39 & 2439.37 \\
$\begin{array}{c}\text { Threshold Limit } \\
\text { Value (TLV) }\end{array}$ & 750 & 750 & & 100 \\
\hline
\end{tabular}

Note: ") italic fonts indicated the value are excess the TLV. The operational condition for the calculation were at $25^{\circ} \mathrm{C}$ and $1 \mathrm{~atm} ;{ }^{2)}$ Environment Ministry Regulation No. 21 / 2008 for TSP. The amount determination for emissions from Coal Fired Power Plant 1 x 660 MW Expansion the combustion was based on emission factors developed by the U.S. EPA as presented in Table 2. Dispersion modeling of pollutants from the chimney into the ambient air was using gas outlet temperature at $120^{\circ} \mathrm{C}$ in accordance with the data obtained from the Adipala power plant while the ambient air temperature was using room temperature. The chimney diameter was obtained using fluid dynamics calculations on which considered as the most effective method. Pollutant dispersion modelling was calculated using the Matlab software ver. 7.8.0.

\section{RESULT AND DISCUSSION}

\section{Emission on Chimney}

The coal combustion carried out to gain energy for driving the turbine will generate pollutant gas such as $\mathrm{SO}_{\mathrm{x}}$ gases from sulfur contained in coal and will produce $\mathrm{NO}_{x}$ gases as nitrogen content in coal as well as the $\mathrm{N}_{2}$ from the air used. An imperfect combustion will result carbon monoxide (CO) while the coal combustion process will result fine particles suspended in the air which will also be dispersed to the surrounding environment.

Emission calculation of coal combustion emissions for power plants was done by taking into account the type of coal used, the combustion process as well as the use of certain technologies that can reduce emissions levels. US EPA has conducted a review of the emissions resulting from the combustion process thus it issued emission factor for each fuel type and accompanying processes. Based on the calculations result, it was obtained pollution emission for modeling scenario using coal consumption as much as 390 tons $/ \mathrm{h}$ and typical coal specifications are presented in Table 3.

Emissions calculations based on coal consumption load and the amount of air would affect the pollutants flow rate into the air. Based on the calculation, the type of typical coal will be generated emissions flow rate for each scenario as presented in Table 4.

Pollutants flow rate generated in Table 4 were used to calculate how many pollutants were removed by power plant based on its criteria scenario. The results of pollutant emissions for each scenario were presented in Table 5. Some pollutant parameters were still above the standard emission. $\mathrm{SO}_{2}$ parameters exceed the standard emission on scenario 1 and 2 while it has met standard emission on scenarios 3 and 4 by adding the volume of air that was used as much as $10 \%$. It would be better if $\mathrm{SO}_{2}$ reducer tools such as 
Table 6. Analysis result for ambient air quality on location

\begin{tabular}{|c|c|c|c|c|c|c|c|}
\hline \multirow{2}{*}{ Code } & \multirow{2}{*}{ Location } & \multirow{2}{*}{ Coordinate } & \multicolumn{4}{|c|}{ Parameter $\left(\mu \mathrm{g} / \mathrm{Nm}^{3}\right)$} & \multirow{2}{*}{ Note } \\
\hline & & & $\mathrm{SO}_{2}$ & $\mathrm{NO}_{2}$ & $\mathrm{CO}$ & TSP & \\
\hline $\mathrm{R} 1$ & $\begin{array}{lcr}\text { North } & \text { Western } & \text { site } \\
\text { Tapak. } & \text { Gaga } & \text { Kiniar } \\
\text { Village } & & \end{array}$ & $\begin{array}{l}S=06^{\circ} 03.554^{\prime} \\
E=106^{\circ} 26.747^{\prime}\end{array}$ & 49.80 & 2.77 & 37.02 & 124.69 & \multirow{8}{*}{$\begin{array}{l}\mathrm{T}=32.0^{\circ} \mathrm{C} \\
\text { Weather: Bright } \\
\mathrm{T}=32.5^{\circ} \mathrm{C} \\
\text { Weather: Bright } \\
\mathrm{T}=32.4^{\circ} \mathrm{C} \\
\text { Weather: Bright } \\
\mathrm{T}=34.5^{\circ} \mathrm{C} \\
\text { Weather: Bright } \\
\mathrm{T}=35.0^{\circ} \mathrm{C} \\
\text { Weather: Bright } \\
\mathrm{T}=29.4^{\circ} \mathrm{C} \\
\text { Weather: Bright } \\
\mathrm{T}=31.8^{\circ} \mathrm{C} \\
\text { Weather: Bright } \\
\text { Environment Ministry } \\
\text { Regulation No. } 21 / 2008\end{array}$} \\
\hline $\mathrm{R} 2$ & Kayu Apus Village & $\begin{array}{l}S=06^{\circ} 05.550^{\prime} \\
E=106^{\circ} 27.415^{\prime}\end{array}$ & 258.09 & 20.15 & 426.94 & 42.87 & \\
\hline R3 & $\begin{array}{l}\text { South Western } \\
\text { Gaga Ilir Village }\end{array}$ & $\begin{array}{l}S=06^{\circ} 04.689^{\prime} \\
E=106^{\circ} 26.499^{\prime}\end{array}$ & 3.09 & 15.27 & 2.97 & 129.01 & \\
\hline R4 & $\begin{array}{l}\text { Western site. Gaga } \\
\text { Kiniar Village }\end{array}$ & $\begin{array}{l}S=06^{\circ} 03.805^{\prime} \\
E=106^{\circ} 26.962^{\prime}\end{array}$ & 22.78 & 10.80 & 186.41 & 39.11 & \\
\hline R5 & $\begin{array}{l}\text { South Western site. } \\
\text { Gaga Tengah Village }\end{array}$ & $\begin{array}{l}S=06^{\circ} 04.106^{\prime} \\
E=106^{\circ} 26.775^{\prime}\end{array}$ & 278.02 & 24.71 & 523.30 & 125.49 & \\
\hline $\mathrm{R} 6$ & $\begin{array}{l}\text { Southern Site. Biawakan } \\
\text { Jaya Village }\end{array}$ & $\begin{array}{l}S=06^{\circ} 05.402^{\prime} \\
E=106^{\circ} 26.996^{\prime}\end{array}$ & 115.60 & 44.01 & 908.70 & 27.78 & \\
\hline \multirow[t]{2}{*}{$\mathrm{R} 7$} & $\begin{array}{l}\text { Site. In front of Baitun } \\
\text { Nur Mosque }\end{array}$ & $\begin{array}{l}S=06^{\circ} 03.604^{\prime} \\
E=106^{\circ} 27.734^{\prime}\end{array}$ & 65.32 & 9.41 & 126.17 & 45.51 & \\
\hline & $\begin{array}{l}\text { Threshold Limit Value } \\
\text { Sampling Time }\end{array}$ & & $\begin{array}{l}365 \\
24 \mathrm{~h}\end{array}$ & $\begin{array}{l}150 \\
24 \mathrm{~h}\end{array}$ & $\begin{array}{l}10.000 \\
24 \mathrm{~h}\end{array}$ & $\begin{array}{l}230 \\
24 \mathrm{~h}\end{array}$ & \\
\hline
\end{tabular}

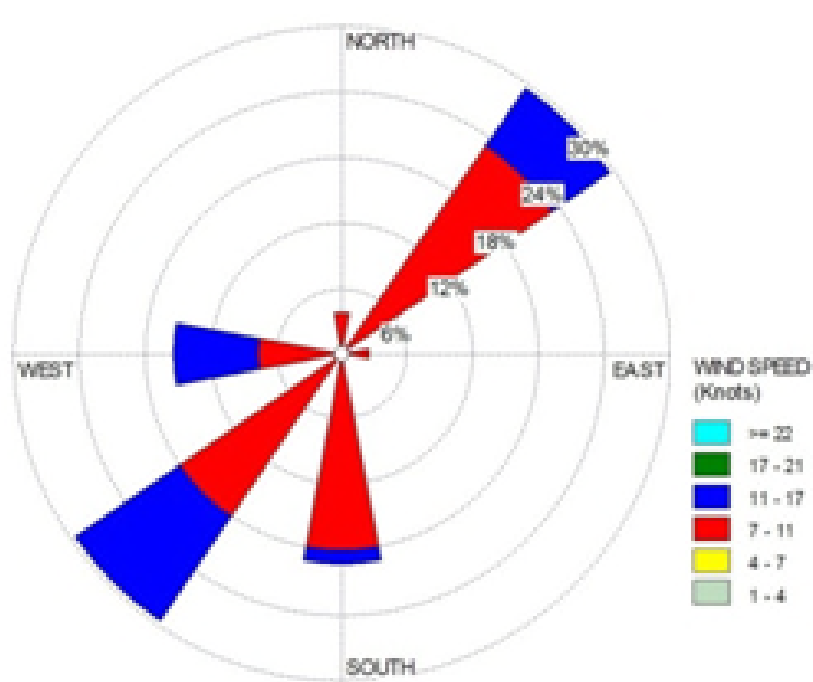

Fig 2. Wind rose in 2001-2011 from Cengkareng Monitoring Station

FDG be added as the emission ranges were close to the Threshold Limit Value. Besides, $\mathrm{NO}_{2}$ parameter has far exceeded the standard emission in all scenarios, thus a tool was needed in order to reduce $\mathrm{NO}_{2}$ such as using a combustion system with low $\mathrm{NO}_{2}$ system (Low $\mathrm{NO}_{x}$ Burner). Moreover, TSP parameters needed an additional tool such Electrostatic Precipitator (ESP) because the amount of dust would be disruptive and far above standard emission if it was without ESP installation.

\section{Pollutant Dispersion into Ambient Air}

Wind direction data showed that the dominant wind direction was blowing from Southwestern and Northeast at speeds ranging from 7-11 knots. The wind roses overview was presented in Fig. 2.

The modeling results of pollutant dispersion into the environment was done by modeling the distribution of pollutants using Gaussian Plume equation taking into account with the wind direction and calculate existing power plant condition on activity areas. Air quality measurement has been conducted on June, 22 - May, 23, 2012 around the operated area of Banten 3 power plant. Ambient air sampling was conducted to determine the condition of the ambient air around the power plant. Sampling points distance were various starting from the closest point on the power plant project site area, then taken into $0-5 \mathrm{~km}$ around the power plant site. The measurement results of ambient air were presented in Table 6.

The monitoring results of ambient air quality in Banten 3 power (Table 6 ) showed that the air condition was in good condition. It can be seen that the location has still natural condition with most areas are agriculture and gardens. Some locations for $\mathrm{SO}_{2}$ concentrations were relatively high because there were people activities such burning garbage and agriculture waste (straw).

PT PLN (Persero) plan to build the power plant 1 x $660 \mathrm{MW}$ capacity would produce more pollutant gas concentrations in the ambient air. Dispersion modeling results for each scenario was performed using the worst case scenario on which the calculation was selected using atmospheric conditions which will give maximum exposure to the ambient air. The flue gas out temperature was $393 \mathrm{~K}$ in rural area. The results of the pollutant dispersion were presented in Fig. 3.

Based on the results of the dispersion calculations, it showed that all the parameters $\left(\mathrm{SO}_{2}\right.$, $\mathrm{NO}_{2}, \mathrm{CO}$, and TSP) met the national ambient air quality 

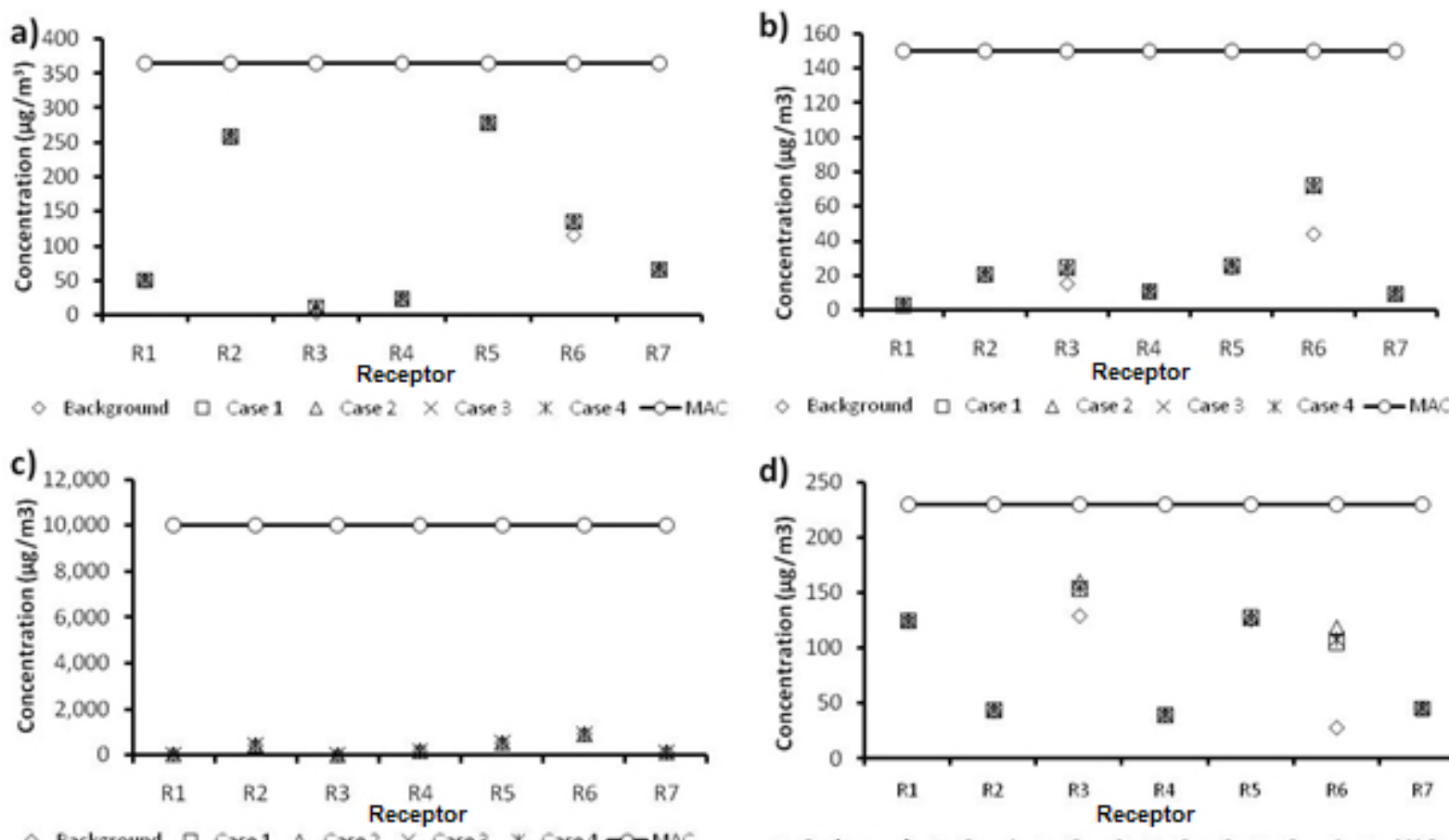

$\circ$ Eackground $\square$ Case $1 \triangle$ Case $2 \times$ Case $3 \times$ Case $4-M-M A C$

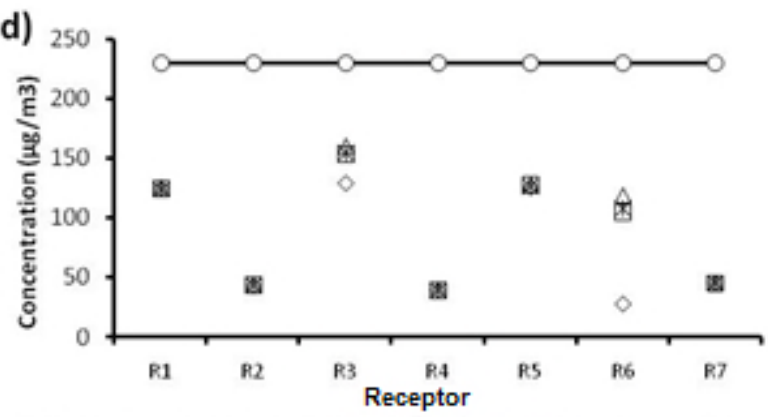

Fig 3. Pollutant gas concentration into the receptor (a) $\mathrm{SO}_{2}$, (b) $\mathrm{CO}$, (c) $\mathrm{NO}_{2}$, (d) TSP (Note: Maximum Allowable Concentration is based on Indonesian Government Regulation No. 41 1999)
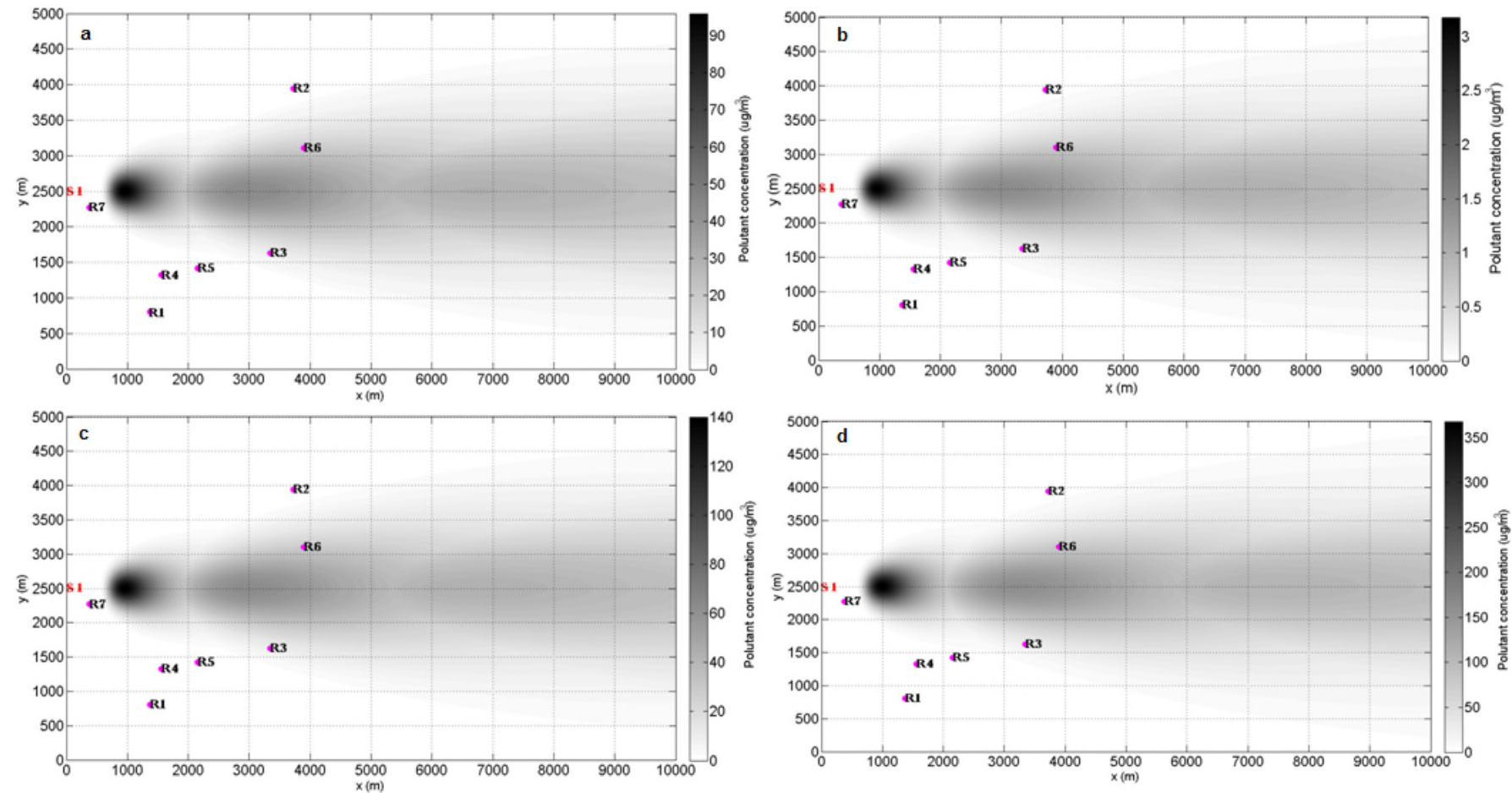

Fig 4. Dispersion of pollutant gases case 1 (a) $\mathrm{SO}_{2}$, (b) $\mathrm{CO}$, (c) $\mathrm{NO}_{2}$, (d) TSP

standard. Air pollutant dispersion from a single stack scenario and stack separated as far as $43 \mathrm{~m}$ showed much different results. The dispersion results for separated stack have tendencies for increasing the maximum concentration distribution and shorten the maximum concentration distance. This phenomenon was due to separated stack would produce lower flow rate pollutant. 
Through the calculation results of the ambient air quality on power plant location taken at the maximum dispersion estimated point from the existing power plant showed that the additional concentration of $\mathrm{NO}_{2}$ and TSP as the result of the increase of power plant capacity. Otherwise, it was not expected to exceed ambient air quality standard. $\mathrm{NO}_{2}$ and TSP pollutant gases can give effect on human health whose affected to pollutant gas exposure in high concentrations. The distribution of each pollutant gases were presented in Fig. 4.

\section{CONCLUSION}

It can be concluded through the simulation results that increasing of plant capacity will also increase the pollutant emissions. $\mathrm{SO}_{2}$ gas on case- 1 and case- 2 and $\mathrm{NO}_{2}$ and TSP on all scenarios were exceeding the emission standards, according to Environment Ministry Regulation No. 21/2008. The determination of ambient air concentration on residential location around the power plant indicates that ambient air concentrations received by receptors are still below the Threshold Limit Value in accordance with Government Regulation No. $41 / 1999$.

\section{ACKNOWLEDGEMENT}

Thankful is acknowledged to PLN (Persero) as funding and partner research.

\section{REFERENCES}

1. Sriram, G., Mohan, N.K., and Gopalasamy, V., 2006, J. Sci. Ind. Res., 65 (4), 321-324.

2. J. Lodge, 1986, Methods of air Sampling and Analysis, $3^{\text {rd }}$ ed., APHA, Washington.

3. Mahapatra, A.D., and Ramjeawon, T., 2011, Water Air Soil Pollut., 219 (1-4), 203-213.

4. Wu, Y-L., Rahmaningrum, D.G., Lai, Y-C., Tu, L-K., Lee, S.J., Wang, L-C., and Chien, G-P., 2012, Aerosol Air Qual. Res., 12, 643-650.

5. Vijayaraghavan, K., Seigneur, C., Bronson, R., Chen, S-Y., Karamchandani, P., Walters, J.T., Jansen, J.J., Brandmeyer, J.E., and Knipping, E.M., 2010, J. Air Waste Manage. Assoc., 60 (3), 287293.
6. Billings, P., 2011, Emissions of Hazard Air Pollutants From Coal-Fired Power Plants, Environmental Health and Engineering, Inc., Washington DC.

7. M. Alhassan, A. Jimoh, 2006, Leonardo J. Sci., 5 (9), 137-148.

8. Green, A.E.S., Singhal, R.P., and Venkateswar, R., 1980, J. Air Pollut. Control Assoc., 30 (7), 773-776.

9. Racoceanu, C., and Capatina, C., 2006, J. Univ. Chem. Technol. Metall., 42 (1), 109-114.

10. Ichikawa, Y,, and Sada, K., 2002, J. Air Waste Manage. Assoc., 52 (3), 313-323.

11. Ma, S., 2010, Energy Power Eng., 2 (3), 190-195.

12. Fatehifar, E., Elkamel, A., Taheri, M., Anderson, W.A., and Abdul-Wahab, S.A., 2007, Environ. Eng. Sci., 24 (6), 795-811.

13. Hicks, T., 2006, Handbook of Mechanical Engineering Calculations, $2^{\text {nd }}$ ed., The McGrawHill, New York.

14. Stockie, J.M., 2011, SIAM Rev., 53 (2), 349-372.

15. Bijaksana, A.M.A., Sjahrul, M., Harun, N., and Djamaluddin, R., 2012, Int. J. Civ. Environ. Eng., 12 (03), 41-47.

16. Kementerian Energi dan Sumber Daya Mineral, 2012, Statistik Batu Bara 2012, http://www.esdm.go.id/statistik/data-sektor-esdm/ cat_view/58-publikasi/240-statistik/337-statistikbatubara.html., accessed on December 10, 2013.

17. The World Bank, 2013, Fossil fuel energy consumption (\% of total), http://data.worldbank.org/indicator/EG.USE.COMM .FO.ZS., accessed on December 10, 2013.

18. Anonymous, 2005, SNI 19-7119.7-2005, Badan Standar Nasional, Jakarta.

19. Anonymous, 2005, SNI 19-7119.2-2005, Badan Standar Nasional, Jakarta.

20. Anonymous, 2005, SNI 19-4845-1998, Badan Standar Nasional, Jakarta.

21. Anonymous, 2005, SNI 19-7119.3-2005, Badan Standar Nasional, Jakarta.

22. Beauchemin, S.S., Hamshari, H.O., and Bauer, M.A., 2009, Int. J. Comput. Appl., 31 (2), 97-108.

23. Veigele, Wm.J., and Head, J.H., 1978, J. Air Pollut. Control Assoc., 28 (11), 1139-1141. 